\title{
The Divisiveness of a Political Party's Nomination Process and Its Effect on U.S. Presidential Elections
}

\section{Youseop Shin}

(Yonsei University)

〈CONTENTS〉

I. Introduction

II. Reevaluating the Divisive Primary Hypothesis: The Issue of Specification

III. Reevaluating the Divisive Primary

Hypothesis: The Issue of Measurement

IV. Model
V. Findings

VI. Primary Divisiveness and Feelings toward Candidates

VII. Discussion

VIII. Conclusion

- Keywords : divisive nomination process, presidential election, responsible voting behavior, partisan voting behavior

\section{【ABSTRACT】}

This article sets up an individual-level model and reassesses the divisive primary hypothesis, focusing on the following two possibilities: (1) Divisive primaries influence voting choices in the presidential election for all voters, not only supporters of the nomination losers; (2) voters' responsible or partisan voting behaviors reduce the impact of divisive primaries on voting decisions in the presidential election. Evidence for the divisive primary hypothesis is limited in the 1988 and 1992 U.S. presidential elections. Instead of negatively responding to the primary divisiveness, voters appear to make responsible and/or partisan voting decisions in presidential elections. In addition, the primary divisiveness is not likely to increase the negativity of voters' feelings toward their nominee. 


\section{I . Introduction}

Divisive primaries can be detrimental to a political party's chance of winning a presidential election. Strong candidates run for their party's nomination, trying to garner media coverage, acquire momentum, and survive the winnowing-out process. ${ }^{1)}$ Candidates of the same political party criticize each other, reveal each other's weaknesses, and ask voters not to support their competitors. Thus, nomination processes can fractionalize the party organization and create factions loyal to the ambitions of individual leaders. ${ }^{2}$ A divisive nomination process can also make voters doubt whether a political party can resolve leadership problems so that it is fit to hold the presidency. As a result, the divisive primary hypothesis states that, after a divisive primary, voters are more likely to defect parties or abstain from voting in the presidential election. This article tests this hypothesis, focusing on presidential elections in the United States where data on vote decisions in primary and presidential elections are available.

Studies have provided general evidence for the impact of divisive primaries on presidential election outcomes. ${ }^{3)}$ Also, state-level presidential election outcomes provide evidence that divisive primaries have an effect on the presidential election. In Table 1, a primary is determined to be divisive if the difference in the state-level percentage of votes in primaries between the nominee and the runner-up is less than 20, as in previous studies. ${ }^{4)}$ According to the first and second columns in Table 1, in all the U.S. presidential elections from 1972 to 2004, except the 1992 and 2000 elections, the ratio of the number of divisive primaries to the total number of primaries is smaller for the winners than for the losers. In the 2000 presidential election, George Bush was the

1) Paul H. Gurian, "Candidate Behavior in Presidential Nomination Campaigns: A Dynamic Model," Journal of Politics 55 (1993), pp. 115-39.

2) V. O. Key, Politics, Parties, Pressure Groups, $5^{\text {th }}$ ed. (New York, 1964); Donald B. Johnson and James R. Gibson, "The Divisive Primary Revisited: Party Activists in Iowa," American Political Science Review 68 (1974), pp. 67-77.

3) Patrick J. Kenney and Tom W. Rice, "The Relationship between Divisive Primaries and General Election Outcomes," American Journal of Political Science 31 (1987), pp. 31-44; James I. Lengle, "Divisive Presidential Primaries and Party Electoral Prospects, 1932-1976," American Politics Quarterly 8 (1980), pp. 261-77; James I. Lengle, Diana Owen, and Molly W. Sonner, "Divisive Nominating Mechanisms and Democratic Party Electoral Prospects," Journal of Politics 57 (1995), pp. 370-83; Priscilla L. Southwell, "The Politics of Disgruntlement: Nonvoting and Defection among Supporters of Nomination Losers, 1968-1984," Political Behavior 8 (1986), pp. 81-95; Walter J. Stone, "The Carryover Effect in Presidential Elections," American Political Science Review 80 (1986), pp. 271-79.

4) See, for example, Lengle (1980); Lengle et al. (1995). 
Table 1. Primary Divisiveness and Presidential Election Results, 1972-2004'

\begin{tabular}{|c|c|c|c|c|}
\hline \multicolumn{2}{|r|}{ Candidate } & $\begin{array}{c}\% \text { of Votes in } \\
\text { Presidential election }\end{array}$ & $\begin{array}{l}\% \text { of Divisive } \\
\text { Primaries }\end{array}$ & $\begin{array}{l}\text { \# of Wins / } \\
\# \text { of States }\end{array}$ \\
\hline \multirow{2}{*}{1972} & McGovern & 37.2 & $47.4(9 / 19)^{3}$ & $0 / 9$ \\
\hline & Nixon & 60.2 & $0(0 / 18)$ & $0 / 0$ \\
\hline \multirow{2}{*}{1976} & Carter & 50.0 & $46.2(12 / 26)$ & $2 / 4$ \\
\hline & Ford & 48.0 & $53.8(14$ / 26) & $2 / 6$ \\
\hline \multirow{2}{*}{1980} & Carter & 41.0 & $39.4(13$ / 33) & $0 / 10$ \\
\hline & Reagan & 50.5 & $24.2(8 / 33)$ & $5 / 5$ \\
\hline \multirow{2}{*}{1984} & Mondale & 40.4 & $71.4(20$ / 28) & $0 / 20$ \\
\hline & Reagan & 58.5 & $0(0 / 25)$ & $0 / 0$ \\
\hline \multirow{2}{*}{1988} & Dukakis & 45.7 & $25(9$ / 36) & $3 / 7$ \\
\hline & Bush & 53.4 & 16.7 (6 / 36) & $4 / 4$ \\
\hline \multirow{2}{*}{1992} & Clinton & 43.0 & $30.6(11 / 36)$ & $9 / 10$ \\
\hline & Bush & 37.5 & $2.6(1 / 38)$ & $0 / 0$ \\
\hline \multirow{2}{*}{1996} & Clinton & 49.2 & $0(0 / 35)$ & $0 / 0$ \\
\hline & Dole & 40.7 & $19(8 / 42)$ & $3 / 8$ \\
\hline \multirow{2}{*}{2000} & Gore & 48.4 & $15(6 / 40)$ & $3 / 3$ \\
\hline & Bush & 47.9 & $19(8 / 42)$ & $2 / 5$ \\
\hline \multirow{2}{*}{2004} & Kerry & 48.3 & $22.2(8 / 36)$ & $2 / 8$ \\
\hline & Bush & 50.7 & $0(0 / 31)$ & $0 / 0$ \\
\hline \multirow{2}{*}{ Total } & Democrat & & $30.4(88$ / 289) & $19 / 71$ \\
\hline & Republican & & $15.5(45$ / 291) & $16 / 28$ \\
\hline
\end{tabular}

1. 20 percent is used as the cut point to determine whether a primary is divisive.

2 . The number of states that the candidate won in the presidential election after the candidate, but not the opposition party's candidate, experienced divisive primaries / the total number of states where only the candidate experienced divisive primaries.

3. The number of divisive primaries that the candidate experienced / the total number of primaries.

winner but Albert Gore won the popular vote. In the 1992 presidential election, economic issues could have played a role in determining election outcomes. ${ }^{5)}$ According to the third column in Table 1, a presidential candidate is more likely to lose a state if the candidate, but not the opposition party's candidate, experienced divisiveness in the state primary. In about two-thirds of the 99 cases in which only one of the two major political parties' presidential candidates experienced a divisive state primary, the candidate who experienced the divisiveness lost the state in the presidential election.

Some studies, however, do not support the divisive primary hypothesis. One study

5) Kathryn M. Doherty and James G. Gimpel, "Candidate Character vs. the Economy in the 1992 Election," Political Behavior 19 (1997), pp. 177-96. 
shows that activity for a nomination contender, even for a loser, tends to increase the level of participation in the presidential election and, once mobilized by the nomination process, voters tend to remain loyal to their party's nominee. ${ }^{6)}$ Another study shows that the impact of primary divisiveness on presidential election outcomes can vary according to election year context such as the current president's approval rating and the unemployment rate. ${ }^{7}$ State-level presidential election outcomes also provide evidence that the divisiveness of primaries does not influence presidential election outcomes. For example, in 1980, Reagan won all five states where only the Republican Party experienced divisive primaries. In 1988, Bush won all four states where only the Republican Party experienced divisive primaries. In 1992, Clinton won nine out of ten states where only the Democratic Party experienced divisive primaries. In 2000, Gore won all three states where only the Democratic Party experienced divisive primaries. In 1980, in the five states where only the Republican Party experienced divisive primaries, the runner-up was George Bush who became Reagan's running mate and thus, the divisive primary hypothesis cannot be appropriately applied in explaining the election outcomes of the five states. In the other three elections, however, the divisiveness of primaries does not seem to have played a decisive role in determining the presidential election outcomes of sixteen states.

With these mixed findings and contradictory evidence in mind, this article reassesses the presidential divisive primary hypothesis, seeking to remedy the weaknesses found in previous studies.

\section{Reevaluating the Divisive Primary Hypothesis: The Issue of Specification}

Previous studies neglected to consider two possibilities in testing the presidential divisive primary hypothesis: 1) Divisive primaries influence voting choices in the presidential election for all voters, not only supporters of the nomination losers; and 2) voters' responsible or partisan voting behaviors reduce the impact of divisive primaries on voting decisions in the presidential election. First, previous studies focused on

6) Walter J. Stone, Lonna Rae Atkeson, and Ronald B. Rapoport, "Turning On or Turning Off? Mobilization and Demobilization Effects of Participation in Presidential Nomination Campaigns," American Journal of Political Science 36 (1992), pp. 665-91.

7) Lonna R. Atkeson, "Divisive Primaries and General Election Outcomes: Another Look at Presidential Campaigns," American Journal of Political Science 42 (1998), pp. 256-71. 
supporters of nomination losers. They assumed that supporters of losing candidates would respond negatively to the divisiveness of primaries and exhibit out-group hostility to the nominee. They neglected to consider the possibility that supporters of the nominee and non-primary voters may also be affected by the divisiveness of primaries. These voters may respond, for example, to the level of nastiness, which tends to increase in a close primary, such that they may abstain from voting in the presidential election.

By considering the impact of divisive primaries on all voters along with its impact on the supporters of losing candidates, this article can test the divisive primary hypothesis more accurately. If the impact of primary divisiveness on supporters of nomination losers is significantly greater than its impact on other voters, the former will be observed after the latter is controlled. Without controlling the latter, one cannot confidently argue that what is observed with the variable that measures the former is the influence that is exerted by primary divisiveness exclusively over the supporters of losing candidates. Nor can it be tested whether primary divisiveness exerts a stronger influence over supporters of losing candidates than over other voters.

Second, factors that encourage voters to make responsible choices can reduce the impact of the divisiveness of primaries on voting decisions in the presidential election. Without controlling the former, one cannot accurately discuss how the divisiveness of primaries affects voting decisions. Studies on American elections have shown that voters tend to show responsible behaviors in the presidential election: Voters' retrospective evaluations of the incumbent president's job performances and prospective evaluations that compare the president and the candidate of the challenging party tend to exert a significant influence over voting decisions in the presidential election. ${ }^{8)}$

Previous studies include some control variables such as presidential approval ratings and the unemployment rate or party incumbency and state party orientation." These variables are not as useful in individual-level analyses of one presidential election as in aggregate-level studies that cover multiple presidential elections. Also, one cannot ascertain to what extent simple economic situations such as the unemployment rate

8) V. O. Key, The Responsible Electorate: Rationality in Presidential Voting, 1936-1960 (Cambridge: Harvard University Press, 1966); Michael S. Lewis-Beck, "Comparative Economic Voting: Britain, France, Germany, Italy," American Journal of Political Science 30 (1986), pp. 31546; Brad Lockerbie, "Prospective Voting in Presidential Elections: 1956 -1988," American Politics Quarterly 20 (1992), pp. 308-25; Youseop Shin, "The Responsible Electorate Theory and Vote Decisions in the 2000 American Presidential Election," Korean Political Science Review 36 (2002), pp. 269-84; Youseop Shin, "The Responsible Electorate Theory and Voters in the Presidential Election," Korean Political Science Review 33 (1999), pp. 77-90.

9) Atkeson (1998); Lengle (1980); Lengle et al. (1995). 
affect the incumbent political party. National economic evaluations can be important when they are mediated by evaluations of the government. ${ }^{10)}$ When using candidate evaluations, one can directly ascertain whether a certain person approves or disapproves of the incumbent president. Thus, one can study responsible voting behavior more directly by using mediated economic evaluations than by using non-mediated evaluations.

Voters may also show partisan behaviors in the presidential election. In the nomination process, partisan voters will vote for a less preferred candidate for a party nomination because that candidate was believed to have a better chance of being elected. ${ }^{11)}$ In the presidential election, these voters, trying to maximize gains by winning the election, will become more supportive of their nominee whether or not the nominee was their preferred nomination candidate, as their nominee faces a stronger challenger in the presidential election.

With these points in mind, this article includes the impact of divisive primaries on all voters in the individual-level model along with its impact on the supporters of losing candidates. This study also includes variables such as candidate evaluations and the other party's primary divisiveness with which voters' responsible or partisan behaviors can be estimated. This article expects voters to be responsible and/or partisan in the presidential election: Once voters' responsible and partisan behaviors are taken into account, presidential primaries should have a limited effect in understanding voting decisions in the presidential election.

\section{Reevaluating the Divisive Primary Hypothesis: The Issue of Measurement}

Studies of the impact of the primary divisiveness on general election outcomes have employed, as the threshold to determine whether a primary was divisive, a 20 percent or less margin of victory between the winner and the runner-up in a state primary and, using the 20 percent margin of victory as the cut point, employed a dichotomous variable that assigns 1 to a primary that is divisive and 0 to one that is not. ${ }^{12}$ Some

10) Lewis-Beck (1986).

11) Walter J. Stone and Alan I. Abramowitz, "Winning May Not Be Everything, But It's More than We Thought: Presidential Party Activists in 1980," American Political Science Review 77 (1983), pp. 945-56; Patrick J. Kenney and Tom W. Rice, "The Psychology of Political Momentum," Political Research Quarterly 47 (1994), pp. 923-38. 
studies define a primary as divisive when its winner earned less than 65 percent of votes. ${ }^{13)}$ This standard is equivalent to a 30 percent margin of victory between the winner and the runner-up.

These operationalizations of the primary divisiveness that utilize the percent margin of victory between the winner and the runner-up in a state primary, however, have a weakness. Divisiveness is not merely present or absent. It is a matter of degree. It may not be realistic to assume that divisiveness exists only when the margin of victory is lower than a certain percentage. With a continuous variable that measures the margin of victory instead of a dichotomous variable, one can discuss primary divisiveness more accurately.

To test the divisive primary hypothesis, it is also necessary to consider Democratic and Republican primary divisiveness relative to each other. ${ }^{14)}$ For example, if both parties experience equally divisive primaries, the resultant loss of voters by one political party in the presidential election is likely to be compensated for by the loss of voters in the other political party. As a result, the primary divisiveness may fail to significantly influence presidential election outcomes. To test this notion, an interaction term, the difference between the Republican nominee's share and the Democratic nominee's share in each state primary votes or a relative divisiveness measure by which the out-party's nominee's share of the primary vote is subtracted from the incumbent party's nominee's share have been employed. ${ }^{15}$

When individual voting decisions are analyzed, however, these relative primary divisiveness measurements are not as appropriate as they are in the aggregate-level studies. To individual voters, the divisiveness of the other political party's primary may not be as meaningful as the divisiveness of their own political party's primary. Also, the impact of primary divisiveness on voting decisions may vary from individual to individual. Thus, when one analyzes individual voting decisions in the presidential election, it is more appropriate to include two separate measures of primary divisiveness of each of the two political parties and to estimate how individuals respond to each political party's primary divisiveness than to weigh equally both political parties'

12) See, for example, Lengle (1980); Lengle et al. (1995).

13) Robert A. Bernstein, “Divisive Primaries Do Hurt: U.S. Senate Races, 1956-1972,” American Political Science Review 71 (1977), pp. 540-45; Andrew Hacker, "Does a Divisive Primary Harm a Candidate's Election Chance," American Political Science Review 59 (1965), pp. 105-10.

14) Richard Born, "The Influence of House Primary Election Divisiveness on General Election Margins, 1962-76," Journal of Politics 43 (1981), pp. 640-61; Kenney and Rice (1987); Atkeson (1998).

15) Kenney and Rice (1987); Atkeson (1998). 
primary divisiveness and take the difference between the two political parties as the measure of the relative primary divisiveness. With these separate measures, it is also possible to test whether voters show partisan behaviors, namely whether they become more supportive of their nominee in the presidential election, when they face a strong candidate of the opposition party.

With these points in mind, this study employs, as the measurement of the primary divisiveness, the nominee's percent margin of victory in each state primary. The divisiveness of the other party's primary, which is measured in the same way, is also included.

All these primary divisiveness measurements have two potential weaknesses. One is that they are based on the percentage of votes in primaries, and thus divisiveness is not directly measured. With regard to this point, one study shows that close primary election outcomes tend to indicate the negativity of a primary campaign. ${ }^{16}$ This article, like previous studies, assumes that the closer the state's primary election outcome is, the more divisive the campaign in the state tends to have been.

The other weakness is that all the primary divisiveness measurements are based on state- $^{-}$or district-level primary outcomes. Thus, they fail to consider the possibility that the impact of the primary divisiveness may be related to the outcome of the entire nomination season, not only to the primary in one's own state. This article assumes that voters may not pay close attention to the characteristics of other states' primaries. In 1988, for example, when 20 percent is the cut point, after divisive primaries in Wisconsin and New York, Democrats in Pennsylvania, Indiana, and Ohio overwhelmingly supported Dukakis. On Super Tuesday, among 16 states, only 4 experienced divisive primaries. A similar tendency was observed in the 1992 Democratic nomination process. Even if some voters pay close attention to the characteristics of other states' primaries, there is no way to pinpoint the states whose primary divisiveness individual voters actually consider. Some voters may pay attention only to their state's primary divisiveness. Others may additionally consider the divisiveness in some adjacent states' primaries or in some important states' primaries. Not all voters will consider divisiveness in all primaries. In addition, previous studies employ state- or district-level primary divisiveness measurements possibly because the use of state- or district-level percentages of votes in primaries is the most practical way of operationalizing primary divisiveness. When primary divisiveness is measured at the national level, it will have a constant value for a nomination season such that its impact cannot be analyzed. Our

16) Paul A. Djupe and David M. Peterson, "The Impact of Negative Campaigning: Evidence from the 1998 Senatorial Primaries," Political Research Quarterly 55 (2002), pp. 845-60. 
study employs a state-level divisiveness measure and thus tests whether primary divisiveness that voters experienced in their state influence their vote choices in the presidential election. The impact of that national-level divisiveness measure on vote choices in the presidential election should be examined over multiple elections when the data become available.

\section{Model}

This article analyzes voting behaviors in the 1988 and 1992 presidential elections for which the American National Election Studies (NES) provides variables that measure voting decisions in the primaries. ${ }^{17)}$ For the 1988 election, Democrats and Republicans are separately analyzed. For the 1992 election, only Democrats are analyzed. In 1988, Democratic nomination process was more divisive than Republican nomination process. In 1992, Republicans did not experience a divisive nomination process except for in the first contest in New Hampshire. ${ }^{18)}$ Also, it has been suggested that primary divisiveness could be more consequential for Democratic candidates than Republican candidates. ${ }^{19)}$

The logistic regression model is employed. The dependent variable measures whether voters, regardless of the primary divisiveness they experienced, supported their party's nominee in the presidential election. This variable assigns 1 to voters who voted for their party's nominee in the presidential election and 0 to voters who abstained or who voted for the other candidates.

Three core independent variables are primary divisiveness, opposition divisiveness, and an interaction term between each voter's own political party's primary divisiveness variable and the supporters of the losing candidates variable. For these variables, the

17) The 1972 and 1976 ANES do not provide retrospective and prospective candidate evaluation variables. The 1984 and 1996 to 2004 ANES do not include variables that measure voting choices in primaries. The 1980 presidential election is not analyzed in this article because, in 1980, a major contender, George Bush, in a highly divisive Republican nomination process, became the running mate so that the divisive primary hypothesis cannot be appropriately tested. Youseop Shin ("Divisive Nomination Process and Presidential Election: The Case of the 2000 Presidential Election in U.S.” 21st Century Political Science Review 17 [2007], pp. 10922) tests the divisive primary hypothesis for the 2000 U.S. presidential election without the primary vote decision variable in the model.

18) For respondents who identified themselves as independents (independent-independents), separate analyses are required. Also, with the 1988 and 1992 ANES, voting behaviors of independents cannot be appropriately estimated because of the small number of cases that are included in the analysis.

19) Lengle et al. (1995). 
percentage difference of votes between nomination candidates is utilized to measure the primary divisiveness. With the primary divisiveness variable, the impact of an individual voter's political party's primary divisiveness on the voter's decision in the presidential election is estimated. The voter in this variable includes not only supporters of nomination losers but also supporters of the nominee and non-primary voters. For this variable, the divisiveness of a state's primary is measured as the absolute values of the percentage difference of votes between the nominee and the runner-up. Thus, the smaller the value, the more divisive a primary is. This difference of votes is expected to describe the divisive nature of primaries, which voters tend to consider when they determine whether or not they will support their nominee in the presidential election, better than the percentage difference in votes between any other two nomination candidates.

The opposition divisiveness variable is included to consider the possibility that the impact of primary divisiveness is relative to the other party's primary divisiveness. For example, if both parties experience equally divisive primaries and if an individual voter equally weighs both parties' primary divisiveness, the primary divisiveness may fail to significantly influence presidential election outcomes. With this variable, our study can also test whether voters show partisan behaviors in the presidential election, namely whether voters tend to become more supportive of their nominee in the presidential election as the other party's candidate experienced less divisive primary in their states.

The interaction term between each voter's own political party's primary divisiveness variable and the supporters of the losing candidates variable estimates the impact that an individual voter's political party's primary divisiveness has on the voter's decision in the presidential election when the voter supported a losing candidate. This variable assigns 0 to the supporters of the nominee. Voters who abstained in primaries may be peripheral voters, ${ }^{20)}$ and they may not respond selectively to primary divisiveness because they did not support the nominee or losers in their state's primary. Thus, this variable also assigns 0 to voters who did not participate in their state's primary. To the supporters of nomination losers, this variable assigns absolute values of percentage difference of votes between the nominee and the candidate whom voters supported in their state's primary.

The other independent variables are supporters of the losing candidates, strength of partisanship, retrospective economic evaluation, and prospective economic evaluation. The supporters of the losing candidates variable, with which the carry-over effect is

20) Barbara Norrander, "Ideological Representativeness of Presidential Primary Voters," American Journal of Political Science 33 (1989), pp. 570-87. 
estimated, assigns 0 to voters who supported their party's nominee in their state's primary and 1 to voters who supported their party's nomination losers. The carry-over effect means that voters who supported nomination losers are more likely to defect or abstain in the presidential election than are voters who supported the nominee. ${ }^{21)}$ Supporters of nomination losers may abstain or defect in the presidential election for various reasons that are not related to the divisiveness of primaries. In their state's primary, voters might support nomination losers because they did not support the nominee's policy positions. In the presidential election, these voters may support the other party's nominee if his/her policy positions are closer to their own. Thus, it may not be appropriate to accept the carry-over effect as evidence of the divisive primary hypothesis. Also, without controlling the carry-over effect, one cannot accurately discuss whether supporters of nomination losers are likely to abstain or defect in the presidential election because they experienced divisiveness in the nomination process.

Since this study considers Democrats and Republicans separately, it needs to control only for the strength of partisanship. Thus, strength of partisanship assigns 3 to strong Democrats or to strong Republicans, 2 to Democrats or to Republicans, and 1 to independent Democrats or to independent Republicans. Retrospective economic evaluation measures voters' opinion of the president's handling of the economy. It is coded as 2 (strongly approve), 1 (approve), -1 (disapprove), and -2 (strongly disapprove). Prospective economic evaluation is measured directly by asking which candidate will best be able to handle the nation's economy. It is coded as 1 (Bush), 0 (same by both/neither), and -1 (Dukakis) in 1988 and as 1 (Bush), 0 (no difference/Perot), and -1 (Clinton) in 1992.

For the three core independent variables, state-level primary divisiveness is calculated according to the Congressional Quarterly's election reports on the candidates' share of votes in each primary. The data for the other independent variables and the dependent variable are from ANES.

Since this study considers Republicans and Democrats separately and since the supporters of the losing candidates variable is included in the model, respondents who said that they had participated in the other political party's primaries are not included in the analyses. There are ten Democrats and 34 Republicans in the 1988 ANES and 12 Republicans and 17 Democrats in the 1992 ANES.

Excluding these types of voters from analyses is appropriate because their responses are likely to be unreliable. Even though they actually participated in the other political

21) Southwell (1986); Stone (1986); Denis G. Sullivan, "Party Unity: Appearance and Reality," Political Science Quarterly 92 (1977-1978), pp. 635-45. 
party's primaries, the divisiveness of their political party's primaries may not significantly influence their voting decisions in the presidential election for several reasons. First, in-group loyalty or out-group hostility towards the Democratic nominee is less likely to develop among Democrats who participated in a Republican primary than among Democrats who participated in a Democratic primary and thus who directly experienced its divisiveness. Second, voters who participated in the other political party's primaries may be core partisans who cast tactical votes in order to make the opposition party nominate a weaker candidate. In the 1988 ANES, 25 out of 34 Republicans and four out of ten Democrats who participated in the other political party's primaries supported nomination losers. In the 1992 ANES, three out of 17 Democrats and five out of 12 Republicans exhibited the same behavior. Third, voters who participated in the other political party's primary may be, in the terminology of John H. Aldrich, "alienated" voters who think that the best candidate of their political party is too poor to be worth supporting and thus who prefer the other party's best candidate, even though they have not experienced the divisiveness of their political party's primary. ${ }^{22)}$ Six out of ten Democrats and nine out of 34 Republicans in the 1988 ANES and 14 out of 17 Democrats and seven out of 12 Republicans in the 1992 ANES supported the opposition party's nominee in the opposition party's primaries.

\section{Findings}

Table 2 summarizes the results of logistic regression analyses for Democrats and Republicans in the 1988 presidential election and Democrats in the 1992 presidential election. According to Table 2, the evidence of the divisive primary hypothesis is not found with the dependent variable, which measures whether Democrats supported their party's nominee in the 1988 presidential election. According to the interaction term, primary divisiveness did not significantly decrease the probability that Democrats who had supported nomination losers would support the nominee in the presidential election. Also, according to the primary divisiveness variable, the probability that Democrats would support their presidential candidate in the presidential election did not significantly decrease when they had experienced a divisive primary in their state. On the other hand, according to the variable that measures the divisiveness of the Republican primaries, in 1988, the probability that Democrats would support their presidential candidate tended to increase as their state's Republican primary became

22) John H. Aldrich, Before the Convention (Chicago: University of Chicago Press, 1980). 
Table 2. Primary Divisiveness and Voting Behaviors in the 1988 and 1992 Presidential Elections

\begin{tabular}{llll}
\hline & \multicolumn{2}{c}{1988} & 1992 \\
& \multicolumn{1}{c}{ Demøcrats } & Republicans & \multicolumn{1}{c}{ Demøcrats } \\
\hline Primary Divisiveness & $-.004(-.03)^{1}$ & $.02(.15)^{* * *}$ & $.003(.02)$ \\
Interaction Term & $.01(.07)$ & $-.06(-.31)^{*}$ & $.015(.05)$ \\
Republican Primary Divisiveness & $.01(.11)^{* *}$ & & $-.015(-.07)$ \\
Democratic Primary Divisiveness & & $-.013(-.08)$ & \\
Supporters of Losing Candidates & $.79(.14)$ & $3.95(.41)^{*}$ & $.23(.002)$ \\
Strength of Partisanship & $.30(.10)^{*}$ & $.83(.27)^{* * *}$ & $.73(.25)^{* * *}$ \\
Retrospective Economic Evaluation & $-.19(-.11)^{* *}$ & $.41(.19)^{* * *}$ & $-.01(.002)$ \\
Prospective Economic Evaluation & $-.82(-.27)^{* * *}$ & $43(.12)^{* *}$ & $-1.70(-.38)^{* * *}$ \\
Constant & $-2.04^{* * *}$ & -.81 & -.45 \\
\hline Nagelkerke R & .247 & .291 & .303 \\
Level of Significance & .000 & .000 & .000 \\
$\mathrm{n}$ & 509 & 439 & 388 \\
\hline
\end{tabular}

$* \mathrm{p}<.05, * * \mathrm{p}<.01,{ }^{* * *} \mathrm{p}<.001$ (two-tailed test).

1. The number in each parenthesis is a standardized coefficient.

less divisive.

According to these three independent variables, Democrats appear to have been partisan in the 1988 presidential election, that is, they, including supporters of nomination losers, were not influenced by the divisiveness of their party's primaries. Also, Democrats became more likely to support their nominee in the presidential election, as their state's Republican primary became less divisive.

Also, Democrats tended to be responsible. According to retrospective and prospective evaluation variables, they based their voting decisions on their evaluations of presidential candidates: When Democrats evaluated the Republican president's handling of the economy more favorably and when Democrats' prospective economic evaluations became more favorable to the Republican Party, they became less likely to support their presidential nominee in the presidential election.

Although Republicans' voting behavior was somewhat different from Democrats' behavior in the 1988 presidential election, the divisive primary hypothesis is not supported by the Republicans' behavior. First, although the impact of primary divisiveness is observed in the model with the dependent variable that measures whether Republicans supported their party's nominee in the presidential election, Republicans, like Democrats, did not appear to negatively respond to the primary divisiveness. According to the primary divisiveness variable in Table 2, Republicans became less likely 
to support their presidential candidate in the 1988 election if they experienced a more divisive primary in their state. According to the interaction term, however, as with Democrats, primary divisiveness did not significantly decrease the probability that Republicans who had supported nomination losers would support the nominee in the presidential election. Instead, Republican supporters of nomination losers became more supportive of their nominee in the presidential election, because they experienced more divisive primaries. Also, according to the supporter of the losing candidates variable, Republicans who had supported a nomination loser in their state's primary were more likely to support their nominee in the presidential election than were Republicans who had supported the nominee in their state's primary, other things being equal. Thus, supporters of nomination losers did not tend to respond negatively to the divisiveness. Nor did they tend to carry over their opposition to their nominee during the nomination process in the presidential election.

Second, in the 1988 presidential election, Republicans were not clearly partisan as the Democratic primary divisiveness variable is not significant $(p=.065)$. Like Democrats, however, Republicans tended to be responsible in that their voting decisions were significantly influenced by their evaluations of presidential candidates.

The divisive primary hypothesis is not supported by the Democrats' behavior in the 1992 presidential election. All the independent variables that are related to primary divisiveness are statistically insignificant. In the model, the dependent variable assigns 0 to Democrats who supported Ross Perot. Thus, in the 1992 presidential election, Democrats, when they experienced divisive primaries, were not more likely to support the third candidate, Perot or more likely to abstain; the presence of a visible third party option did not create a different dynamic and cause voters who experienced divisive primaries to abandon the Democratic Party.

In summary, the individual-level analyses of voting behaviors in the 1988 and 1992 presidential elections provide only limited evidence for the primary divisiveness hypothesis. No evidence was found for the impact of primary divisiveness on supporters of nomination losers. Instead of negatively responding to their political party's primary divisiveness, both Democrats and Republicans tended to show partisan and/or responsible voting behaviors. According to the standardized coefficients in Table 2, partisan behavior, which is indicated by the opposition divisiveness variable, tends to be almost as strong as responsible behavior, which is indicated by two candidate evaluation variables. ${ }^{23)}$ Although the impact of primary divisiveness is observed with the Republican

23) For the estimation of standardized logistic regression coefficients, see Scott Menard, Applied Logistic Regression Analysis (Thousand Oaks: Sage, 1995), pp. 44-49. 
model in Table 2, the impact is not limited to supporters of nomination losers. In addition, according to standardized coefficients, the impact can be cancelled out by partisan and/or responsible behaviors.

The evidence for the carry-over effect is also limited. In addition, the effect, when observed, does not work in a direction that is detrimental to a political party's electoral prospect. Thus, voters, once mobilized by the nomination process, are likely to remain loyal to their political party. ${ }^{24)}$ However, they are not likely to be unconditionally loyal because they are also likely to be responsible. Also, voters are not mobilized just by the nomination process. Instead, they are likely to be partisan, considering the relative divisiveness of the opposition party's primaries.

\section{Primary Divisiveness and Feelings toward Candidates}

Individual-level analyses of voting behaviors in the 1988 and 1992 presidential elections provide limited evidence for the primary divisiveness hypothesis. As an additional check, this study tests whether primary divisiveness is related to voters' feelings toward their party's nominee and toward the other party's nominee. Employing the 1980 NES panel data, a previous study shows that respondents' prenomination preferences, which are measured with feeling thermometer scales, carry over to influence voting decisions in the presidential election. ${ }^{25}$ ) As the divisive primary hypothesis states, if voters respond negatively to the divisiveness of primaries and if they thus become less likely to make rational and responsible voting decisions in the presidential election, voters' feelings toward candidates of their party and the other party will serve as a link between their response to the divisiveness of primaries and their voting decisions in the presidential election. Although the primary election divisiveness does not directly influence voting decisions in the presidential election, it may influence voting decisions indirectly through voters' feelings towards candidates of their party and the other party.

To test whether primary divisiveness is related to voters' feelings toward their party's nominee and toward the other party's nominee, this study conducts ordinary regression analyses with two dependent variables, each of which measures individual voters' feeling thermometers toward their political party's nominee and toward the other party'

24) See Stone et al. (1992).

25) Patrick J. Kenney and Tom W. Rice, "Presidential Prenomination Preferences and Candidate Evaluations," American Political Science Review 82 (1988), pp. 1309-19. 
Table 3. Primary Divisiveness and Feeling Thermometers in the 1988 and 1992 Presidential Elections

\begin{tabular}{lllllllc}
\hline & \multicolumn{4}{c}{1988} & \multicolumn{2}{c}{1992} \\
\cline { 2 - 7 } & \multicolumn{2}{c}{ Democrats } & \multicolumn{2}{c}{ Republicans } & \multicolumn{2}{c}{ Democrats } \\
\cline { 2 - 7 } & Dukakis & Bush & Bush & Dukakis & Clinton & Bush \\
\hline Primary Divisiveness & -.06 & .02 & -.04 & .04 & -.01 & $.12^{*}$ \\
Interaction Term & -.10 & .13 & -.12 & .07 & .01 & .02 \\
Republican Primary Divisiveness & -.02 & -.03 & & & .13 & -.07 \\
Democratic Primary Divisiveness & & & .04 & .001 & & \\
Supporters of Losing Candidates & 1.08 & $-8.37^{*}$ & 4.97 & -5.18 & -4.34 & -7.34 \\
Strength of Partisanship & 1.83 & -.68 & $4.88^{* * *}$ & -1.09 & $-6.99^{* * *}$ & -1.76 \\
Retrospective Economic Evaluation & -1.42 & $5.00^{* * *}$ & $2.44^{* * *}$ & $-2.72^{* * *}$ & .23 & $5.42^{* * *}$ \\
Prospective Economic Evaluation & $-6.14^{* * * *}$ & $5.46^{* * *}$ & $6.09^{* * *}$ & $-7.58^{* * *}$ & $-13.13^{* * * *}$ & $15.84^{* * *}$ \\
Constant & $54.71^{* * *}$ & $73.40^{* * *}$ & $70.03^{* * *}$ & $40.06^{* * *}$ & $41.75^{* * *}$ & $63.57^{* * *}$ \\
\hline Nagelkerke R & .069 & .168 & .191 & .115 & .279 & .239 \\
Level of Significance & .000 & .000 & .000 & .000 & .000 & .000 \\
$\mathrm{n}$ & 505 & 505 & 440 & 435 & 545 & 550 \\
\hline
\end{tabular}

${ }^{*} \mathrm{p}<.05,{ }^{* *} \mathrm{p}<.01,{ }^{* * *} \mathrm{p}<.001$ (two-tailed test).

s nominee. These feeling thermometers come from NES.

According to the primary divisiveness variable in Table 3, Democrats' feelings toward the Democratic candidate and toward the Republican candidate do not appear to become significantly higher or lower according to whether they experienced divisiveness in the 1988 Democratic primary. Also, according to the interaction term, Democratic primary divisiveness did not have any additional impact on the feelings of supporters of Democratic nomination losers toward the Democratic nominee or toward the Republican nominee.

In addition, according to the supporters of the losing candidates variable, feeling thermometer levels for the Democratic nominee were not significantly lower among Democrats who supported nomination losers than among Democrats who supported the nominee, other things being equal. Also, feeling thermometer levels for the Republican nominee tended to be slightly lower among Democrats who supported nomination losers than among Democrats who supported the Democratic nominee, other things being equal.

The divisiveness of primaries does not appear to be significantly related with Republicans' feelings toward the Democratic candidate and toward the Republican candidate. According to Table 3, the variables that are related to the divisiveness of primaries are not statistically significant, regardless of whether the dependent variable 
measures feelings toward the Republican nominee or toward the Democratic nominee.

Evidence that primary divisiveness is related with Democrats' feelings toward the Democratic candidate and toward the Republican candidate is also lacking in the 1992 presidential election. According to the primary divisiveness variable in Table 3 , Democrats' feelings toward the Republican candidate were significantly influenced by the Democratic primary divisiveness in 1992. However, it did not work as expected: As Democrats experienced a more divisive primary, they became less favorable toward the Republican nominee. According to the interaction term, Democratic primary divisiveness did not have any additional impact on the feelings of the supporters of Democratic nomination losers toward the Democratic nominee or toward the Republican nominee.

In addition, according to the supporters of the losing candidates variable, feeling thermometer levels for the Democratic nominee were not significantly lower among Democrats who supported nomination losers than among Democrats who supported the nominee, other things being equal. Also, feeling thermometers levels for the Republican nominee were not significantly higher among Democrats who supported nomination losers than among Democrats who supported the Democratic nominee, other things being equal.

From the results in Table 3, the limited evidence for the divisive primary hypothesis in Table 2 can be explained: When voters, including supporters of nomination losers, experience a divisive primary in their state, they do not tend to develop negative feelings toward their nominee. In addition, compared with voters who supported the nominee, voters who supported nomination losers do not tend to have more negative feelings toward their nominee or more positive feelings toward the other political party's nominee.

In addition, according to Table 3 , the limited evidence for the divisive primary hypothesis in Table 2 needs to be understood with caution: Even if voters appear to consider the divisiveness of their state's primary in making voting decisions in the presidential election, it may not cause overtly sentimental voting behavior.

\section{Discussion}

The model in this study has several possible weaknesses. This article checked whether Table 2 would present different results if these weaknesses are accounted for. First, in 1988 and 1992, the Republican Party did not have a primary in New York. Since this study considers the divisiveness of the Republican primaries along with the divisiveness 
of the Democratic primaries, respondents from New York are excluded from the analysis. The Democratic primary in New York, however, was highly divisive both in 1988 and in 1992. Thus, without Democrats from New York in the analysis, estimation of the impact of primary divisiveness on Democrats' voting behaviors in the presidential election might be less accurate.

When this study sets the divisiveness of the hypothetical Republican primary in New York at 100 in order to avoid excluding the Democrats from New York, the logistic regression analyses produce almost the same results. The coefficients and levels of significance of some variables change only slightly. The overall interpretations of the coefficients remain unchanged. By setting the hypothetical Republican primary divisiveness in New York at 100, which indicates that the primary was not divisive at all, this study maximized the impact of the Democratic primary divisiveness in New York on Democrats' voting behaviors in the presidential election. Thus, evidence for the divisive primary hypothesis is not likely to be observed when the hypothetical Republican primary divisiveness score in New York is lower than 100.

Second, early divisive primaries may be less harmful to nominees than late divisive primaries. Time may heal wounds. Also, the divisiveness of late primaries when many candidates dropped out may more clearly represent the divisive nature of the nomination competition.

In 1988, eight out of nine divisive Democratic primaries were held in the first half of the nomination process. Among them, six were held in the first 30 days, including four on March 8. All six divisive Republican primaries were held in the first 30 days. Thus, even if time heals wounds, the interaction variable between the week of the primary and its divisiveness would not have had a significant effect in 1988.

In 1992, divisive Democratic primaries occurred more widely and were observed until near the end of the nomination process. The interaction term between primary divisiveness and the week of the primary, which assigns 1 to the first week of the nomination process and 16 to the last week of the nomination process, is not statistically significant in the model. Thus, even when the later primaries are divisive, the divisiveness does not appear to significantly influence voting choices in the presidential election. The coefficients of other independent variables change slightly, but the overall interpretation does not have to change.

Third, it may be that the percentage difference of votes between the nominee and the other top vote-getter in a primary, not the nomination loser whom a voter actually supported in a primary, reflects primary divisiveness, which in turn influences the supporters of nomination losers in the presidential election. When replacing the 
interaction term with a new one that assigns to the supporters of losing candidates the absolute values of the percentage difference of votes between the nominee and the other top vote-getter in a primary, the winner when the nominee was a loser in the primary or the runner-up when the nominee was the winner, Table 2 has almost identical results. The only notable change is that the interaction term becomes statistically insignificant for Republicans in Table 2. In Table 3, Democratic primary divisiveness has an additional impact on the feelings of the supporters of Democratic nomination losers toward the Republican nominee(.24, $\mathrm{p}<.05)$. However, it did not work as the divisive primary hypothesis describes, that is, as supporters of Democratic nomination losers experienced a more divisive primary, they became less favorable toward the Republican nominee.

Fourth, this study does not include in the model some factors that could affect the propensity of a voter to defect. These factors include the ideological distance variable, which measures the degree to which each Democrat is more conservative than the Democratic nominee or to which each Republican is more liberal than the Republican nominee, and demographic factors such as African-American, Jewish, and education.

When included in the model, the ideological distance variable, African-Americans, and education do not significantly change the results. ${ }^{26)}$ Voters still appear to be responsible and/or partisan in the presidential election.

There are also some methodological problems in the expanded model. The number of cases included in the analysis drops substantially. For example, for the 1988 models, the number of cases drops from 509 to 320 and from 439 to 207. Any gain from the inclusion of the three or more variables is likely to be cancelled out by this loss of available cases.

The choice of preference between the original model and the expanded model may be a matter of subjective judgment. This article prefers the original one. No matter how many factors are included in the model, threats to the external validity will remain. Also, these factors are not of major concern in this article. Even with the expanded model, the conclusion of this article does not have to be substantially revised. There seems to be no reason to prefer the expanded model, because it sacrifices the parsimoniousness of explanation and the randomness of data.

26) There are not enough cases for Jewish voters in the 1988 and 1992 NES. 


\section{Conclusion}

Analyzing the 1988 and 1992 U.S. presidential elections, this article found only limited individual-level evidence for the divisive primary hypothesis. ${ }^{27)}$ In the presidential election, voters who identify themselves with one of the two major political parties and who participated in their party's primary, when their party's primary was divisive in their state, do not tend to become less supportive of their presidential nominee. Also, primary divisiveness does not significantly decrease the probability that voters would support the nominee in the presidential election even when they supported nomination losers. Perhaps a more fundamental finding against the divisive primary hypothesis is that, according to the relationship between feeling thermometers and primary divisiveness, voters do not appear to make voting decisions on the basis of a grudge formed in the primary election.

Even if voters are influenced by primary divisiveness, its negative impact is likely to be mitigated by voters' partisan and/or responsible voting behaviors. As studies of elections and campaigns have argued, in the presidential election, voters tend to base their vote decisions on party identification and their evaluations of candidates. Moreover, other things being equal, voters are likely to rally around their party's nominee when their political party experiences a more divisive nomination process than that of the other political party, that is, when their nominee appears to be weaker than the other party's nominee in the presidential election. It has been shown that, in the nomination process, voters tend to consider the electability of their party's candidates or else display bandwagon behavior. ${ }^{28)}$ According to the findings of this article, voters do not respond passively to electability; instead, they actively try to improve the electability

27) In Table 2, variance inflation factors (VIF) for the interaction term and the supporters of losing candidates variable are from 2.8 to 3.3 for Democrats and 5.60 for Republicans. VIFs for the other independent variables are smaller than 1.3. The VIFs for the interaction term and the supporters of the losing candidates variable are somewhat high especially for Republicans, although they are less than 10, which may be an indication of serious multicollinearity. See John Neter, William Wasserman, and Michael H. Kutner, Applied Linear Statistical Models: Regression, Analysis of Variance, and Experimental Designs, 3d ed. (Boston: Irwin, 1990). Thus, it seems to be necessary to interpret the two variables, especially those of the Republican model in Table 2, cautiously. Their coefficients may be statistically less significant than they would be without the multicollinearity problem. The impact of multicollinearity, however, seems to be limited in that these two variables are consistently insignificant in most equations. Also, when they are insignificant, they are highly insignificant so that improving the mulitcollinearity problem is not expected to bring about any notable changes in the level of significance.

28) Kenney and Rice (1994); Stone and Abramowitz (1983). 
of their candidate in the presidential election if their candidate appears to be weaker than the opposition candidate.

The findings in this article are not in agreement with the observations in many previous aggregate-level studies of the divisive primary hypothesis and in Table 1 of this paper. As with the relationship between a divisive nomination processes and congressional election outcomes, ${ }^{29)}$ candidates' electoral vulnerabilities may explain the discrepancy between individual- and aggregate-level observations. If no strong candidate emerges in a nomination process, more candidates are likely to enter the nomination competition, and thus the nomination process is likely to become more divisive. The candidate who wins the nomination is likely to face further difficulties in the presidential election, even if primary divisiveness does not hurt the nominee's electoral prospects. Thus, divisive primaries may appear to be related to the aggregatelevel presidential election outcome because a political party that experiences primary divisiveness is likely to have a weaker candidate whose electoral prospect is likely to be low, ${ }^{30}$ rather than because individual voting decisions are significantly influenced by primary divisiveness. ${ }^{31)}$

29) Patrick J. Kenney, "Sorting Out the Effects of Primary Divisiveness in Congressional and Senatorial Elections," Western Political Quarterly 41 (1988), pp. 765-77; Jeffrey Lazarus, "Unintended Consequences: Anticipation of General Election Outcomes and Primary Election Divisivenes," Legislative Studies Quarterly 30 (2005), pp. 435-61.

30) See Stone et al. (1992).

31) The discrepancy between individual- and aggregate-level observations may stem from the over-reporting tendency of primary vote for the nominee in ANES. See Lonna R. Atkeson, "Sure, I Voted for the Winner! Overreport of the Primary Vote for the Party Nominee in the National Election Studies," Political Behavior 21 (1999), pp. 197-215. In this article, however, this possibility is limited because, as Atkeson argues, the over-reporting tendency, if it really exists, is expected to support the divisive primary hypothesis. Thus, it cannot be used to explain the observations in this article, which provide only limited or no evidence for the divisive primary hypothesis and for the carry-over effect. 


\section{REFERENCES}

Aldrich, John H. Before the Convention. Chicago: University of Chicago Press, 1980.

Atkeson, Lonna Rae. "Divisive Primaries and General Election Outcomes: Another Look at Presidential Campaigns.” American Journal of Political Science 42 (1998), pp. 256-71.

"Sure, I Voted for the Winner! Overreport of the Primary Vote for the Party Nominee in the National Election Studies.” Political Behavior 21 (1999), pp. 197215.

Bernstein, Robert A. "Divisive Primaries Do Hurt: U.S. Senate Races, 1956-1972." American Political Science Review 71 (1977), pp. 540-45.

Born, Richard. "The Influence of House Primary Election Divisiveness on General Election Margins, 1962-76.” Journal of Politics 43 (1981), pp. 640-61.

Campbell, Angus, Philip E. Converse, Warren E. Miller, and Donald E. Stokes. The American Voter. New York: Wiley, 1960.

Djupe, Paul A. and David M. Peterson. "The Impact of Negative Campaigning: Evidence from the 1998 Senatorial Primaries.” Political Research Quarterly 55 (2002), pp. 84560.

Doherty, Kathryn M. and James G. Gimpel. "Candidate Character vs. the Economy in the 1992 Election.” Political Behavior 19 (1997), pp. 177-96.

Gurian, Paul H. "Candidate Behavior in Presidential Nomination Campaigns: A Dynamic Model." Journal of Politics 55 (1993), pp. 115-39.

Hacker, Andrew. "Does a Divisive Primary Harm a Candidate's Election Chance." American Political Science Review 59 (1965), pp. 105-10.

Johnson, Donald B. and James R. Gibson. "The Divisive Primary Revisited: Party Activists in Iowa.” American Political Science Review 68 (1974), pp. 67-77.

Kenney, Patrick J. "Sorting Out the Effects of Primary Divisiveness in Congressional and Senatorial Elections.” Western Political Quarterly 41 (1988), pp. 765-77.

Kenney, Patrick J. and Tom W. Rice. "The Relationship between Divisive Primaries and General Election Outcomes.” American Journal of Political Science 31 (1987), pp. 3144.

Kenney, Patrick J. and Tom W. Rice. "Presidential Prenomination Preferences and Candidate Evaluations.” American Political Science Review 82 (1988), pp. 1309-19. 
Kenney, Patrick J. and Tom W. Rice. "The Psychology of Political Momentum.” Political Research Quarterly 47 (1994), pp. 923-38.

Key, V. O. Politics, Parties, Pressure Groups, $5^{\text {th }}$ ed. New York: Thomas Y. Crowell Company, 1964.

. The Responsible Electorate: Rationality in Presidential Voting, 1936-1960. Cambridge: Harvard University Press, 1966.

Lazarus, Jeffrey. "Unintended Consequences: Anticipation of General Election Outcomes and Primary Election Divisiveness." Legislative Studies Quarterly 30 (2005), pp. 435-61.

Lengle, James I. "Divisive Presidential Primaries and Party Electoral Prospects, 19321976." American Politics Quarterly 8 (1980), pp. 261-77.

Lengle, James I., Diana Owen, and Molly W. Sonner. "Divisive Nominating Mechanisms and Democratic Party Electoral Prospects.” Journal of Politics 57 (1995), pp. 370-83.

Lewis-Beck, Michael S. "Comparative Economic Voting: Britain, France, Germany, Italy.” American Journal of Political Science 30 (1986), pp. 315-46.

Lockerbie, Brad. "Prospective Voting in Presidential Elections: 1956-1988." American Politics Quarterly 20 (1992), pp. 308-25.

Menard, Scott. Applied Logistic Regression Analysis. Thousand Oaks: Sage, 1995.

Neter, John, William Wasserman, and Michael H. Kutner. Applied Linear Statistical Models: Regression, Analysis of Variance, and Experimental Designs. 3d ed. Boston: Irwin, 1990.

Norrander, Barbara. "Ideological Representativeness of Presidential Primary Voters." American Journal of Political Science 33 (1989), pp. 570-87.

Shin, Youseop. "The Responsible Electorate Theory and Voters in the Presidential Election.” Korean Political Science Review 33 (1999), pp. 77-90. . "The Responsible Electorate Theory and Vote Decisions in the 2000 American Presidential Election.” Korean Political Science Review 36 (2002), pp. 269-84. "Divisive Nomination Process and Presidential Election: The Case of the 2000 Presidential Election in U.S." 21 $1^{\text {st }}$ Century Political Science Review 17 (2007), pp. 10922.

Southwell, Priscilla L. "The Politics of Disgruntlement: Nonvoting and Defection among Supporters of Nomination Losers, 1968-1984.” Political Behavior 8 (1986), pp. 8195. 
Stone, Walter J. "The Carryover Effect in Presidential Elections." American Political Science Review 80 (1986), pp. 271-79.

Stone, Walter J. and Alan I. Abramowitz. "Winning May Not Be Everything, But It's More than We Thought: Presidential Party Activists in 1980." American Political Science Review 77 (1983), pp. 945-56.

Stone, Walter J., Lonna Rae Atkeson, Ronald B. Rapoport. "Turning On or Turning Off? Mobilization and Demobilization Effects of Participation in Presidential Nomination Campaigns." American Journal of Political Science 36 (1992), pp. 66591.

Sullivan, Denis G. "Party Unity: Appearance and Reality." Political Science Quarterly 92 (1977-1978), pp. 635-45. 